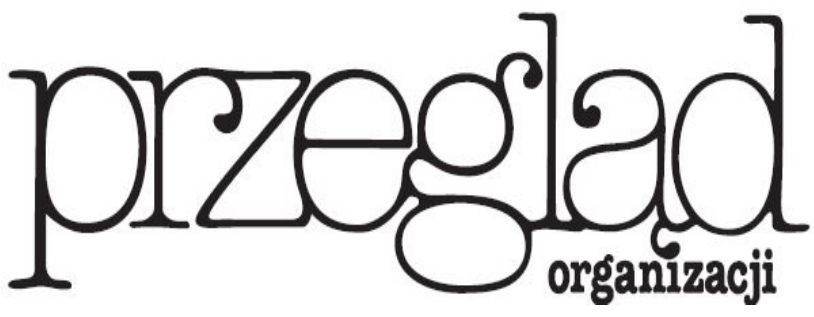

Miesięcznik TNOiK

Założył Karol Adamiecki w 1926 r.

\title{
WYBÓR PARTNERÓW WSPÓŁDZIALANIA JAKO JEDEN Z ELEMENTÓW TREŚCI STRATEGII RELACYJNEJ
}

https://doi.org/10.33141/po.2019.04.02

\section{Agnieszka Sopińska}

\section{Wprowadzenie}

W iększość badaczy zajmujących się strategią relacyjną nie definiuje samego pojęcia, a jedynie odnosi się do konkretnych relacji, opisując je na określonych ich kontinuach (Chun-ju Flora, 2005; Lefaix-Durand i in., 2005; De Wit, Meyer, 2007), koncentruje się na logice strategii relacyjnej (Czakon, 2017) bądź odnosi strategię relacyjną do poszczególnych grup podmiotów, np. strategie lańcucha dostaw (Iyer i in., 2014), strategie relacji z klientem (Buttle, 2004) lub specyfiki relacji, np. strategie współpracy (Faulkner, De Rond, 2000; Child i in., 2005) czy strategie koopetycji (Chin $i$ in., 2008; Yami i in., 2010; Dahl i in., 2016).

Brak jednolitej definicji pojęcia strategii relacyjnej w literaturze przedmiotu wymusza każdorazowe jej dookreślenie. $\mathrm{W}$ prezentowanych $\mathrm{w}$ artykule badaniach przyjęto następującą definicję strategii relacyjnej: „strategia relacyjna
Przegląd Organizacji, Nr 4 (951), 2019, ss. 10-17 www.przegladorganizacji.pl (CTowarzystwo Naukowe Organizacji i Kierownictwa (TNOiK) to ciągły i dynamiczny proces wyborów odnoszących się do nawiązywania, rozwijania i wycofywania się z relacji współpracy i koopetycji z różnymi, kluczowymi dla firmy podmiotami rynku, dokonywanych intencjonalnie w warunkach niepewności otoczenia (barier, presji, szans) i przy ograniczonych zasobach w celu tworzenia i przechwytywania wartości, utrzymania potencjału rozwojowego organizacji i otrzymywania renty relacyjnej" (Zakrzewska-Bielawska, 2017, s. 184). Zgodnie z powyższą definicją, na treść strategii relacyjnej składają się cztery rodzaje wyborów strategicznych: wybór celu strategii relacyjnej określony przez sposób tworzenia i apropriacji (zawłaszczania) wartości z relacji międzyorganizacyjnych; wybór kluczowego(ych) partnera(ów) współdziałania międzyorganizacyjnego; wybór dynamiki międzyorganizacyjnej wyrażającej się 
w relacji współpracy i/lub koopetycji; oraz wybór sposobu kształtowania relacji międzyorganizacyjnych (tj. tworzenia, rozwijania i wycofywania się), obejmujący ich emergentność i/lub intencjonalność (Zakrzewska-Bielawska, 2017).

Celem poniższego artykułu jest omówienie jednej ze składowych treści strategii relacyjnej, jaką jest wybór kluczowych partnerów współdziałania. Omówienie powyższego wyboru zostanie dokonane na gruncie teoretycznym i empirycznym. Podstawę dla wnioskowania teoretycznego stanowi krytyczna analiza literatury przedmiotu, natomiast podstawę dla wnioskowania empirycznego - wyniki badań terenowych i pilotażowych, zrealizowanych $\mathrm{w}$ ramach projektu badawczego NCN (nr UMO-2015/17/B/HS4/00982) pt. „Strategia relacyjna sensu largo przedsiębiorstw funkcjonujących w Polsce"1.

\section{Wybór kluczowych partnerów współdziałania międzyorganizacyjnego na gruncie teorii}

W artykule przyjmuje się, że wybór kluczowych partnerów współdziałania międzyorganizacyjnego obejmuje dwa konstrukty: identyfikację typów partnerów relacji oraz identyfikację kryteriów selekcji tych partnerów.

Partnerzy organizacji, najczęściej określani w literaturze przedmiotu mianem interesariuszy, to: zidentyfikowane grupy lub jednostki, które mogą oddziaływać na osiąganie celów organizacji albo na które oddziałują cele osiągane przez organizację (Freeman, Reed, 1983, s. 91; Freeman, 1984); wszyscy ci, którzy są zainteresowani organizacją, jej działalnością i jej osiągnięciami (EFQM, 2007, s. 31); wszystkie grupy, które są lub mogą być dotknięte przez działania lub sukces organizacji (NIST, 2008, s. 60); ci aktorzy, którzy dostarczają koniecznych środków albo wspomagają organizację, a których środki mogą być wycofane w przypadku, jeżeli ich potrzeby lub oczekiwania nie zostaną spełnione (Klefsjö i in., 2008, s. 124) czy wreszcie - osoby lub grupy osób zainteresowane jakimikolwiek decyzjami lub działaniami organizacji (Norma PN-EN ISO 26000:2009).

Interesariusze podlegają wielu klasyfikacjom i podziałom. Z racji ograniczonej objętości artykułu autorka skupi się na podziale interesariuszy na dwie kategorie: interesariuszy zewnętrznych i interesariuszy wewnętrznych (Stoner i in., 1997, s. 80-81). Powyższy podział to konsekwencja kategoryzacji otoczenia przedsiębiorstwa na: otoczenie wewnętrzne i zewnętrzne, przy czym otoczenie zewnętrzne podlega dalszemu podziałowi na: otoczenie bezpośrednie (bliższe, celowe lub sektorowe) oraz otoczenie pośrednie (dalsze, makrootoczenie). Mianem interesariuszy wewnętrznych określa się grupy lub osoby z otoczenia wewnętrznego przedsiębiorstwa. Są to: pracownicy, akcjonariusze, rada nadzorcza. Natomiast mianem interesariuszy zewnętrznych określa się podmioty i organizacje $z$ otoczenia zewnętrznego bezpośredniego przedsiębiorstwa. Są to więc: konkurenci; dostawcy; nabywcy; instytucje finansowe; organizacje władzy państwowej i samorządowej; grupy szczególnych interesów, czyli organizacje społeczne, organizacje konsumenckie; konsorcja branżowe; media, związki zawodowe.
Ponieważ celem prezentowanych w artykule badań była identyfikacja strategii relacyjnej na poziomie międzyorganizacyjnym, stąd w niniejszym opracowaniu identyfikację typów partnerów współdziałania ograniczono do interesariuszy zewnętrznych.

W literaturze przedmiotu brak jest jednej, uniwersalnej typologii partnerów współdziałania międzyorganizacyjnego, która byłaby stosowana przez wszystkich badaczy. Przeciwnie, można dostrzec pewien subiektywizm w tym zakresie determinowany przez cel badawczy. Jednak pomimo braku uniwersalnej typologii pewne kategorie podmiotów powtarzają się w większości klasyfikacji i podziałów. Są to następujące kategorie podmiotów: dostawcy, nabywcy oraz konkurenci - z zastrzeżeniem, iż ci ostatni (konkurenci) przez część badaczy zaliczani są do interesariuszy jedynie w sytuacji zachodzenia relacji wymiany $\mathrm{z}$ przedsiębiorstwem (Malhotra, Agarwal, 2002, s. 13-14).

Przyjmując za podstawowe kryterium klasyfikacji fakt położenia lub jego brak na ścieżce ekonomicznej (Billington, Davidson, 2013, s. 1464-1465; Feller i in., 2009, s. 298; Yan, Azadegan, 2017, s. 23), w artykule proponuje się autorski podział partnerów relacji międzyorganizacyjnych. Obejmuje on cztery podstawowe typy partnerów: (1) dostawców; (2) odbiorców/klientów; (3) konkurentów oraz (4) tzw. inne podmioty (tab. 1). Pierwsze trzy typy partnerów to podmioty ze ścieżki ekonomicznej, czwarty typ obejmuje podmioty spoza ścieżki ekonomicznej. W ramach tzw. „innych podmiotów” autorka proponuje dalszy podział na następujące kategorie: jednostki naukowo-badawcze; konsorcja branżowe; organizacje społeczne; organizacje konsumenckie; organizacje finansowe oraz organizacje rządowe i samorządowe.

Tabela 1. Autorski podział typów partnerów współdziałania międzyorganizacyjnego

\begin{tabular}{|c|c|}
\hline Operacyjny pomiar konstruktu & Referencje \\
\hline $\begin{array}{l}\text { 1. Nawiązujemy i rozwijamy relacje } \\
\mathrm{z} \text { dostawcami }\end{array}$ & \multirow{11}{*}{$\begin{array}{l}\text { J. Feller, P. Finnegan, } \\
\text { J. Hayes, Ph. O’Reilly, } \\
\text { (2009, s. 298); } \\
\text { C. Billington, } \\
\text { R. Davidson } \\
\text { (2013, s. 1464-1465); } \\
\text { A. Zakrzewska- } \\
\text {-Bielawska (red.), } \\
\text { (2014, s. 365); } \\
\text { T. Yan, A. Azadegan, } \\
\text { (2017, s. 23); } \\
\text { A. Sopińska, } \\
\text { W. Mierzejewska, } \\
\text { (2017, s. 103-117); } \\
\text { A. Sopińska, } \\
\text { P. Dziurski, } \\
\text { (2018, s. 99) }\end{array}$} \\
\hline $\begin{array}{l}\text { 2. Nawiązujemy i rozwijamy relacje } \\
\text { z odbiorcami/klientami }\end{array}$ & \\
\hline $\begin{array}{l}\text { 3. Nawiązujemy i rozwijamy relacje } \\
\text { z konkurentami }\end{array}$ & \\
\hline $\begin{array}{l}\text { 4. Nawiązujemy i rozwijamy relacje } \\
\mathrm{z} \text { innymi podmiotami, w tym: }\end{array}$ & \\
\hline $\begin{array}{l}\text { z jednostkami naukowo-badawczymi } \\
\text { (np. szkołami wyższymi, instytutami } \\
\text { badawczymi itp.) }\end{array}$ & \\
\hline z konsorcjami branżowymi & \\
\hline z organizacjami społecznymi & \\
\hline z organizacjami konsumenckimi & \\
\hline z organizacjami finansowymi & \\
\hline $\begin{array}{l}\text { z organizacjami rządowymi } \\
\text { i samorządowymi }\end{array}$ & \\
\hline z innymi podmiotami (jakimi?) & \\
\hline
\end{tabular}

Źródto: opracowanie własne 
Drugim elementem zawierającym się w ramach wyboru kluczowych partnerów współdziałania międzyorganizacyjnego jest określenie kryteriów selekcji (doboru) powyższych partnerów. Podobnie jak w przypadku typów partnerów współdziałania międzyorganizacyjnego, tu także brak jest zgodności co do zestawu kryteriów, którymi przedsiębiorstwa powinny posługiwać się, szukając partnerów. Większość badaczy bądź listę kryteriów doboru partnerów dostosowuje do specyfiki współpracy przedstawianej w danym opracowaniu lub do specyfiki badanego rynku, bądź uwzględnia jedynie wybrane kryteria selekcji, chcąc $\mathrm{w}$ ten sposób podkreślić szczególną rolę danego parametru. Na dowód tego w tabeli 2 autorka artykułu prezentuje przykłady kryteriów selekcji (doboru) partnerów współdziałania międzyorganizacyjnego, proponowanych przez wybranych autorów.

$\mathrm{Na}$ podstawie wyselekcjonowania kryteriów powtarzających się oraz ich pogrupowania w odrębne kategorie

Tabela 2. Kryteria selekcji (doboru) partnerów współdziatania międzyorganizacyjnego proponowane przez wybranych autorów

\begin{tabular}{|c|c|}
\hline Autorzy & Kryteria selekcji partnerów \\
\hline $\begin{array}{l}\text { P. Lasserre } \\
(1984, \text { s. 43-49) }\end{array}$ & $\begin{array}{l}\text { Dopasowanie strategiczne: wizja strategiczna, } \\
\text { strategiczne znaczenie projekt, presje } \\
\text { Dopasowanie zasobów: wcześniejsze } \\
\text { doświadczenia we wspólnych } \\
\text { przedsięwzięciach, technologie, zasoby } \\
\text { kierownicze i finansowe, zaangażowanie }\end{array}$ \\
\hline $\begin{array}{l}\text { L. Ellram } \\
(1990, \text { s. 8-14) }\end{array}$ & $\begin{array}{l}\text { Kwestie finansowe (wyniki ekonomiczne } \\
\text { i finansowe stabilność) } \\
\text { Kwestie organizacyjne i strategiczne (poczucie, } \\
\text { zaufanie, dopasowanie strategiczne, struktura } \\
\text { organizacyjna dostawcy itp.) } \\
\text { Kwestie technologiczne (ocena zakładów } \\
\text { produkcyjnych, możliwości projektowych itp.) } \\
\text { Inne czynniki (zapis bezpieczeństwa, } \\
\text { referencje biznesowe) }\end{array}$ \\
\hline $\begin{array}{l}\text { T.S. Cavusgil } \\
\text { i C. Evirgen } \\
(1997, \text { s. } 73-86)\end{array}$ & $\begin{array}{l}\text { Kryteria dotyczące partnerów: charakterystyka } \\
\text { partnera, kompatybilność, motywacja, } \\
\text { zaangażowanie, rzetelność, ochrona praw } \\
\text { własności } \\
\text { Kryteria związane z zadaniami: zasoby } \\
\text { finansowe, zasoby marketingowe, obsługa } \\
\text { klienta, zasoby techniczne, działania B\&R, } \\
\text { zasoby organizacyjne, zasoby produkcyjne }\end{array}$ \\
\hline $\begin{array}{l}\text { G. Duysters, G. Kok } \\
\text { i M. Vaandrager } \\
(1999, \text { s. 343-351) }\end{array}$ & $\begin{array}{l}\text { Pozycja konkurencyjna } \\
\text { Wspólne cele }\end{array}$ \\
\hline $\begin{array}{l}\text { A.Al-Khalifa } \\
\text { i S.E. Peterson } \\
(1999, \text { s. 1064-1081) }\end{array}$ & $\begin{array}{l}\text { Więzi, preferencje osobiste, sieć społeczna, } \\
\text { relacje, personalna zgodność } \\
\text { Reputacja } \\
\text { Specyficzne dla danego typu współpracy } \\
\text { umiejętności, kompetencje, infrastruktura, } \\
\text { technologia, zasoby niematerialne }\end{array}$ \\
\hline $\begin{array}{l}\text { M.A. Hitt, } \\
\text { M.T. Dacin, } \\
\text { E. Levitas, } \\
\text { J. L.Arregle } \\
\text { i A. Borza } \\
(2000, \text { s. } 449-467)\end{array}$ & $\begin{array}{l}\text { Komplementarność } \\
\text { Chęć dzielenia się wiedzą } \\
\text { Umiejętność nabywania umiejętności, } \\
\text { umiejętność uczenia się od partnera } \\
\text { Wcześniejsze doświadczenia we współpracy } \\
\text { Koszty, cena, koszty alternatyw } \\
\text { Jakość } \\
\text { Pozycja finansowa, zasoby finansowe }\end{array}$ \\
\hline $\begin{array}{l}\text { B.R. Barringer } \\
\text { i J.S. Harrison } \\
(2000, \text { s. } 367-403)\end{array}$ & $\begin{array}{l}\text { Kryteria stosowane przez menedżerów dla } \\
\text { osiągnięcia własnych celów, niezależnie od } \\
\text { potrzeb firmy } \\
\text { Więzi, preferencje osobiste, sieć społeczna, } \\
\text { relacje, personalna zgodność }\end{array}$ \\
\hline
\end{tabular}

\begin{tabular}{|c|c|}
\hline Autorzy & Kryteria selekcji partnerów \\
\hline $\begin{array}{l}\text { R. Angels } \\
\text { i R. Nath } \\
\text { (2000, s. 241-255); } \\
\text { R. Angeles } \\
\text { i R. Nath } \\
(2003 \text {, s. 59-84) }\end{array}$ & $\begin{array}{l}\text { Komunikacja } \\
\text { Zaangażowanie, zaangażowanie zarządu } \\
\text { Elastyczność } \\
\text { Chęć współpracy } \\
\text { Specyficzne dla danego typu współpracy } \\
\text { umiejętności, kompetencje, infrastruktura, } \\
\text { technologia, zasoby niematerialne }\end{array}$ \\
\hline $\begin{array}{l}\text { H. Lau, W. Lee } \\
\text { i P.K.H. Lau } \\
(2001, \text { s. } 376-395)\end{array}$ & $\begin{array}{l}\text { Pozycja finansowa, zasoby finansowe } \\
\text { Reputacja } \\
\text { Koszty, cena, koszty alternatyw } \\
\text { Jakość }\end{array}$ \\
\hline $\begin{array}{l}\text { A.B. Pidduck } \\
(2006, \text { s. 262-276) }\end{array}$ & $\begin{array}{l}\text { Dostępność zasobów } \\
\text { Reputacja } \\
\text { Polityka } \\
\text { Uniwersalność } \\
\text { Specyficzne dla danego typu współpracy } \\
\text { umiejętności, kompetencje, infrastruktura, } \\
\text { technologia, zasoby niematerialne } \\
\text { Więzi, preferencje osobiste, sieć społeczna, } \\
\text { relacje, personalna zgodność }\end{array}$ \\
\hline $\begin{array}{l}\text { R. Ding, } \\
\text { C.H. Dekker } \\
\text { i T Groot } \\
(2013 \text {, s. } 140-155)\end{array}$ & $\begin{array}{l}\text { Zaufanie } \\
\text { Podobieństwo kulturowe } \\
\text { Reputacja }\end{array}$ \\
\hline $\begin{array}{l}\text { A. Aguezzoul } \\
(2014, \text { s. 69-78) }\end{array}$ & $\begin{array}{l}\text { Lokalizacja } \\
\text { Elastyczność } \\
\text { Więzi, preferencje osobiste, sieć społeczna, } \\
\text { relacje, personalna zgodność } \\
\text { Specyficzne dla danego typu współpracy } \\
\text { umiejętności, kompetencje, infrastruktura, } \\
\text { technologia, zasoby niematerialne } \\
\text { Koszty, cena, koszty alternatyw } \\
\text { Jakość } \\
\text { Profesjonalizm } \\
\text { Pozycja finansowa, zasoby finansowe }\end{array}$ \\
\hline $\begin{array}{l}\text { A. Sopińska, } \\
\text { P. Dziurski } \\
(2018, \text { s. 95-97) }\end{array}$ & $\begin{array}{l}\text { Posiadana wiedza } \\
\text { Posiadane relacje } \\
\text { Posiadane inne zasoby } \\
\text { Zaufanie do podmiotu wynikające } \\
\text { z wcześniejszej współpracy } \\
\text { Wszystkie wymienione }\end{array}$ \\
\hline
\end{tabular}


autorka artykułu zaproponowała własną listę kryteriów selekcji partnerów relacji, obejmującą pięć kryteriów: (1) dopasowanie technologiczne; (2) dopasowanie strategiczne, rozumiane jako zbieżność celów i motywów podjęcia współpracy; (3) dopasowanie relacyjne; (4) stopień zaufania; (5) więzi społeczne.

Ponieważ kryteria (1) i (3) wymagały doprecyzowania, stąd w ramach kryterium (1) „dopasowania technologicznego" autorka zaproponowała następujące podkategorie: możliwości techniczne partnerów; komplementarność zasobów oraz zbieżność bazy wiedzy. Z kolei, w ramach kryterium (3) „dopasowanie relacyjne” wyróżniła: zorientowanie na współpracę długoterminową; bliskość kulturową oraz bliskość geograficzną. Autorską propozycję kryteriów selekcji partnerów relacji zawiera tabela 3.

Tabela 3. Autorska propozycja kryteriów selekcji partnerów relacji

\begin{tabular}{|c|c|}
\hline $\begin{array}{l}\text { Kryteria selekcji } \\
\text { partnerów relacji }\end{array}$ & Referencje \\
\hline $\begin{array}{l}\text { 1. Dobieramy partnerów } z \text { uwagi na } \\
\text { dopasowanie technologiczne, } w \text { tym: }\end{array}$ & \multirow{11}{*}{$\begin{array}{l}\text { P. Lasserre } \\
\text { (1984, s. 43-49); } \\
\text { L. Ellram } \\
\text { (1990, s. 8-14); } \\
\text { G. Duysters, G. Kok } \\
\text { i M. Vaandrager } \\
\text { (1999, s. 343-351); } \\
\text { R. Ding, } \\
\text { C.H. Dekker } \\
\text { i T. Groot } \\
\text { (2013, s. 140-155); } \\
\text { A. Aguezzoul } \\
\text { (2014, s. 69-78) }\end{array}$} \\
\hline możliwości techniczne partnerów & \\
\hline komplementarność zasobową & \\
\hline zbieżne bazy wiedzy & \\
\hline $\begin{array}{l}\text { 2. Dobieramy partnerów z uwagi na } \\
\text { dopasowanie strategiczne, tj. zbieżność } \\
\text { celów i motywów podjęcia współpracy; }\end{array}$ & \\
\hline $\begin{array}{l}\text { 3. Dobieramy partnerów } \mathrm{z} \text { uwagi na } \\
\text { dopasowanie relacyjne, } \mathrm{w} \text { tym: }\end{array}$ & \\
\hline $\begin{array}{l}\text { zorientowanie na współpracę } \\
\text { długoterminową }\end{array}$ & \\
\hline bliskość kulturową & \\
\hline bliskość geograficzną & \\
\hline $\begin{array}{l}\text { 4. Dobieramy partnerów } \mathrm{z} \text { uwagi na stopień } \\
\text { zaufania do nich }\end{array}$ & \\
\hline $\begin{array}{l}\text { 5. Dobieramy partnerów z uwagi na więzi } \\
\text { społeczne }\end{array}$ & \\
\hline
\end{tabular}

Źródto: opracowanie wtasne

Omówione powyżej dwie składowe wyboru partnerów współdziałania międzyorganizacyjnego (typ partnera relacji oraz kryteria selekcji partnerów relacji) zostały poddane empirycznej egzemplifikacji.

\section{Metoda badawcza}

$\mathbf{Z}$ agadnienie wyboru partnerów współdziałania stanowiło jeden z czterech elementów treści strategii relacyjnej diagnozowanej $\mathrm{w}$ ramach szerszego projektu badawczego, finansowanego przez Narodowe Centrum Nauki (Nr UMO-2015/17/B/HS4/00982) pt. „Strategia relacyjna sensu largo przedsiębiorstw funkcjonujących w Polsce". Badania empiryczne realizowane w ramach powyższego projektu obejmowały trzy etapy: etap I - badania terenowe; etap II - badania eksperckie; etap III - badania pilotażowe oraz właściwe.

Prezentowane w artykule wyniki dotyczą dwóch etapów: etapu I oraz badań pilotażowych w ramach etapu III. W etapie I (badania terenowe) jako metodę badawczą zastosowano metodę wywiadu, przy użyciu techniki wywiadu indywidualnego, częściowo-strukturyzowanego, przy czym narzędzie badawcze stanowiły dyspozycje do wywiadu w postaci pytań otwartych i zamkniętych. Etap III badań zrealizowano przy wykorzystaniu metody badań ankietowych i użyciu techniki CATI (ang. Computer Assisted Telephone Interview). Badania terenowe przeprowadzono od listopada 2016 roku do końca lipca 2017 roku, natomiast badania pilotażowe w ramach III etapu - od października do grudnia 2018 roku.

W obu prezentowanych badaniach próba badawcza obejmowała te same 53 przedsiębiorstwa. Dobór próby był probabilistyczny, losowo-warstwowy. Operat losowania stanowiła baza Rejestru Gospodarki Narodowej (REGON). Respondentami byli właściciele lub kadra kierownicza najwyższego szczebla. Wśród 53 zbadanych podmiotów dominowały przedsiębiorstwa: o długim stażu funkcjonowania, tj. ponad 20 lat na rynku (31 firm); prowadzące działalność produkcyjną (28 firm); z dominującym kapitałem krajowym (46 firm), w tym: 43 deklarowało kapitał krajowy jako wyłączny, a trzy jako dominujący; o zasięgu krajowym (20 firm) lub lokalnym (15 firm). Wart podkreślenia jest długi staż funkcjonowania badanych firm, pozwalający uznać, iż badane podmioty charakteryzowały się odpowiednim doświadczeniem w zakresie tworzenia, rozwijania czy też wycofywania się z relacji międzyorganizacyjnych. Poszczególne zmienne (typ partnera współdziałania oraz zastosowane kryteria selekcji partnerów) mierzono na 7-stopniowej skali Likerta.

\section{Wyniki badań}

W ybór partnerów współdziałania w ramach strategii relacyjnej podlegał diagnozie w ramach dwóch etapów postępowania badawczego: etapie I - badania terenowe oraz etapie III - badania pilotażowe.

Przeprowadzone badania terenowe (I etap) pozwoliły zidentyfikować typy partnerów, z którymi badane przedsiębiorstwa wchodziły $\mathrm{w}$ relacje, oraz ocenić znaczenie poszczególnych typów partnerów z perspektywy budowania ich przewagi konkurencyjnej (tab. 4).

Badane przedsiębiorstwa najczęściej wskazywały na wejście $\mathrm{w}$ relacje $\mathrm{z}$ czterema typami podmiotów: klientami (wszystkie firmy), dostawcami (50 podmiotów), $\mathrm{z}$ organizacjami finansowymi (43 jednostki) oraz konkurentami (41 firm). W ocenie respondentów, nawiązanie relacji z powyższymi typami podmiotów miało również największe znaczenie dla budowania przewagi konkurencyjnej analizowanych przedsiębiorstw. Świadczy o tym wartość mediany na poziomie 6 , co należy interpretować, iż 50\% respondentów oceniło relacje $\mathrm{z}$ tymi podmiotami za istotne lub kluczowe ${ }^{2}$. 
Tabela 4. Typy podmiotów, z którymi przedsiębiorstwa weszty w relacje międzyorganizacyjne i ich znaczenie z perspektywy budowania przewagi konkurencyjnej badanych przedsiębiorstw

\begin{tabular}{|l|c|c|c|c|c|}
\hline & \multirow{2}{*}{$\begin{array}{c}\text { Typ podmiotów } \\
\text { T relacje }\end{array}$} & \multicolumn{4}{c|}{$\begin{array}{c}\text { Znaczenie dla budowy przewagi } \\
\text { konkurencyjnej firmy }\end{array}$} \\
\cline { 4 - 6 } & N & $\bar{X}$ & Sd & M & Qr \\
\hline dostawcy & 50 & 5,92 & 0,80 & 6 & 1 \\
\hline odbiorcy & 53 & 6,21 & 0,72 & 6 & 1 \\
\hline konkurenci & 41 & 4,29 & 1,08 & 5 & 2 \\
\hline jednostki naukowo-badawcze & 37 & 4,65 & 1,29 & 5 & 1 \\
\hline konsorcja branżowe & 37 & 4,81 & 1,02 & 5 & 0 \\
\hline organizacje społeczne & 33 & 4,57 & 1,17 & 5 & 1 \\
\hline organizacje konsumenckie & 31 & 4,35 & 1,08 & 5 & 1 \\
\hline organizacje finansowe & 43 & 5,65 & 0,84 & 6 & 1 \\
\hline organizacje rządowe i samorządowe & 31 & 4,90 & 1,11 & 5 & 2 \\
\hline
\end{tabular}

$\mathrm{N}$ - liczba przedsiębiorstw, $\overline{\boldsymbol{X}}$ - średnia, Sd - odchylenie standardowe, $M$ - mediana, Qr - kwartylowy rozstęp Źródło: badania własne na podstawie badań terenowych (I etap studiów); N=53

Tabela 5. Typy podmiotów, z którymi przedsiębiorstwa aktywnie i systematycznie rozwijają relacje

\begin{tabular}{|c|c|c|c|c|c|c|}
\hline Wyszczególnienie & $\begin{array}{l}\text { Nie } \\
\text { zgadzam } \\
\operatorname{się~}(\mathbf{N})\end{array}$ & $\begin{array}{l}\text { Trudno } \\
\text { powiedzieć } \\
\text { (N) }\end{array}$ & $\begin{array}{l}\text { Zgadzam } \\
\operatorname{się~}(\mathrm{N})\end{array}$ & $\bar{x}$ & Sd & $\mathrm{Me}$ \\
\hline $\begin{array}{l}\text { 1. Nasze przedsiębiorstwo stale utrzymuje relacje } \\
\text { z różnymi podmiotami }\end{array}$ & 10 & 0 & 43 & 4,91 & 1,54 & 5 \\
\hline $\begin{array}{l}\text { 2. Rozróżniamy (dzielimy) partnerów na tych } \\
\text { kluczowych dla firmy i pozostałych }\end{array}$ & 9 & 0 & 44 & 5,06 & 1,49 & 5 \\
\hline $\begin{array}{l}\text { 3. Aktywnie i systematycznie rozwijamy relacje } \\
\text { współpracy z kluczowymi dostawcami }\end{array}$ & 20 & 0 & 33 & 4,42 & 1,93 & 6 \\
\hline $\begin{array}{l}\text { 4. Aktywnie i systematycznie rozwijamy relacje } \\
\text { współpracy z kluczowymi odbiorcami/ } \\
\text { klientami }\end{array}$ & 16 & 0 & 37 & 4,83 & 1,84 & 6 \\
\hline $\begin{array}{l}\text { 5. Aktywnie i systematycznie rozwijamy relacje } \\
\text { współpracy z wybranymi konkurentami }\end{array}$ & 47 & 0 & 6 & 2,75 & 1,24 & 2 \\
\hline \multicolumn{7}{|l|}{$\begin{array}{l}\text { 6. Aktywnie i systematycznie rozwijamy relacje } \\
\text { współpracy z innymi podmiotami, w tym: }\end{array}$} \\
\hline z jednostkami naukowo-badawczymi & 48 & 0 & 5 & 2,64 & 1,15 & 2 \\
\hline $\mathrm{z}$ organizacjami branżowymi & 38 & 0 & 15 & 3,26 & 1,55 & 3 \\
\hline z organizacjami społecznymi & 48 & 0 & 5 & 2,62 & 1,08 & 2 \\
\hline z organizacjami finansowymi & 44 & 0 & 9 & 3,04 & 1,37 & 3 \\
\hline z organizacjami rządowymi i samorządowymi & 41 & 0 & 12 & 3,38 & 1,35 & 3 \\
\hline $\begin{array}{l}\text { 7. Utrzymujemy relacje z podmiotami, które } \\
\text { aktualnie/na chwilę obecną nie przynoszą } \\
\text { oczekiwanych korzyści biznesowych, ale mogą } \\
\text { je przynieść w przyszłości }\end{array}$ & 42 & 0 & 11 & 2,96 & 1,30 & 3 \\
\hline $\begin{array}{l}\text { 8. Jesteśmy uwikłani w relacje, } \mathrm{z} \text { których } \\
\mathrm{z} \text { różnych względów nie możemy się wycofać }\end{array}$ & 51 & 0 & 2 & 2,28 & 0,77 & 2 \\
\hline
\end{tabular}

Uwaga: w tabeli dokonano pogrupowania odpowiedzi w trzy grupy: nie zgadzam się (oceny od 1 do 3); trudno powiedzieć (ocena 4); zgadzam się (oceny od 5 do 7) w oparciu o skalę Likerta Źródło: opracowanie wtasne na podstawie badań pilotażowych (III etapu studiów); N=53 
Tabela 6. Kryteria doboru partnerów współpracy międzyorganizacyjnej w świetle badań

\begin{tabular}{|c|c|c|c|c|c|c|}
\hline Kryteria doboru partnerów & $\begin{array}{l}\text { Nie zgadzam się } \\
(\mathbf{N})\end{array}$ & $\begin{array}{l}\text { Trudno powiedzieć } \\
\text { (N) }\end{array}$ & $\begin{array}{l}\text { Zgadzam się } \\
\text { (N) }\end{array}$ & $\bar{X}$ & Sd & $\mathrm{Me}$ \\
\hline $\begin{array}{l}\text { 1. Partnerów do współpracy dobieramy ze } \\
\text { względu na jasno określone kryteria }\end{array}$ & 0 & 0 & 53 & 6,25 & 0,52 & 6 \\
\hline $\begin{array}{l}\text { 2. Dobieramy partnerów do współpracy ze } \\
\text { względu na: ich możliwości (dopasowanie) } \\
\text { technologiczne }\end{array}$ & 8 & 1 & 44 & 5,26 & 1,15 & 6 \\
\hline $\begin{array}{l}\text { zbieżność celów współpracy (dopasowanie } \\
\text { strategiczne) }\end{array}$ & 4 & 3 & 46 & 5,51 & 0,93 & 6 \\
\hline posiadane zasoby (dopasowanie zasobowe) & 4 & 5 & 44 & 5,55 & 0,97 & 6 \\
\hline bliskość / podobieństwo kulturowe & 6 & 4 & 43 & 4,96 & 1,07 & 5 \\
\hline stopień zaufania do nich & 0 & 1 & 52 & 5,70 & 0,57 & 6 \\
\hline reputację/prestiż podmiotu & 0 & 1 & 52 & 5,75 & 0,55 & 6 \\
\hline bliskość geograficzną & 6 & 3 & 44 & 5,02 & 1,08 & 5 \\
\hline więzi personalne (znajomości, przyjaźnie) & 41 & 1 & 11 & 3,04 & 1,21 & 3 \\
\hline silną pozycję podmiotu na rynku & 0 & 0 & 53 & 5,81 & 0,48 & 6 \\
\hline
\end{tabular}

Uwaga: w tabeli dokonano pogrupowania odpowiedzi w trzy grupy: nie zgadzam się (oceny od 1 do 3); trudno powiedzieć (ocena 4); zgadzam się (oceny od 5 do 7) na skali Likerta

Źródło: opracowanie własne na podstawie badań pilotażowych (III etap studiów); N=53

Ponieważ badania terenowe (etap I) pozwoliły jedynie zidentyfikować sam fakt „wejścia badanych przedsiębiorstw $\mathrm{w}$ relacje" $\mathrm{z}$ określonym typami podmiotów, jednak nie dawały odpowiedzi, czy relacje powyższe są rozwijane przez przedsiębiorstwa, to $\mathrm{w}$ etapie III postępowania badawczego (badania pilotażowe) diagnozie poddana została kwestia „aktywnego i systematycznego rozwijania relacji” $\mathrm{z}$ poszczególnymi typami podmiotów. Warto zaznaczyć, iż analizie poddane zostały ponownie te same 53 przedsiębiorstwa, co w badaniach terenowych. Uzyskane wyniki zawarto w tabeli 5 .

Większość badanych przedsiębiorstw stale utrzymywało relacje z różnymi podmiotami (43 wskazań na odpowiedź „zgadzam się”) oraz dzieliło swych partnerów na tych kluczowych dla firmy i pozostałych (44 podmioty), co jest działaniem racjonalnym $\mathrm{z}$ punktu widzenia budowania strategii relacyjnej. Pomimo tego badane przedsiębiorstwa aktywnie i systematycznie rozwijały relacje jedynie $\mathrm{z}$ dwoma typami partnerów: odbiorcami/klientami (37 wskazań na oceny 5-7 w skali Likerta) oraz dostawcami (33 wskazania na oceny 5-7). Wyraźnie zabrakło innych kategorii podmiotów, wskazywanych w I etapie badań (chodzi o organizacje finansowe i konkurentów). Można zatem wnioskować, iż z perspektywy strategii relacyjnej bardziej istotne jest aktywne i systematyczne rozwijanie relacji z kluczowymi partnerami, a nie sam fakt wejścia w te relacje.

Największe rozbieżności pomiędzy samym faktem wejścia $\mathrm{w}$ relacje $\mathrm{z}$ danym podmiotem a aktywnym i systematycznym rozwojem tych relacji można było zauważyć w przypadku kategorii podmiotów: „konkurenci”. Aż 41 badanych podmiotów potwierdziło fakt wejścia $\mathrm{w}$ relacje z konkurentami (etap I badań), a jedynie 6 podmiotów aktywnie i systematycznie rozwijało relacje współpracy $\mathrm{z}$ nimi. Można $\mathrm{z}$ tego wnioskować, iż przedsiębiorstwa nie wchodziły $\mathrm{z}$ konkurentami $\mathrm{w}$ relacje wymiany, a jedynie rywalizacji.

Podobne rozbieżności dało się zauważyć w przypadku kategorii podmiotu - ,jednostki naukowo-badawcze”. Zaledwie 5 z 53 przedsiębiorstw zadeklarowało rozwój relacji z jednostkami naukowo-badawczymi, podczas gdy na sam fakt wejścia $\mathrm{w}$ takie relacje wskazało 37 podmiotów (etap I badań). Możliwe, że w tym przypadku do rozwoju relacji z jednostkami naukowo-badawczymi zniechęcały przedsiębiorstwa bariery formalne obowiązujące na styku świata nauki i biznesu.

Co ciekawe, badane przedsiębiorstwa miały dużą swobodę $\mathrm{w}$ świadomym kształtowaniu relacji $\mathrm{z}$ różnymi podmiotami, bowiem nie były uwikłane $w$ relacje, z których $\mathrm{z}$ różnych względów nie mogłyby się wycofać (jedynie 2 podmioty wskazały na takie uwikłanie). Mimo to przedsiębiorstwa wyraźnie nie przejawiały aktywnej postawy odnośnie do rozwoju relacji $\mathrm{z}$ następującymi typami podmiotów: jednostkami naukowo-badawczymi (48 wskazań), konkurentami (47 wskazań), organizacjami społecznymi (48 wskazań) oraz organizacjami finansowymi (44 wskazań).

Badania prowadzone $\mathrm{w}$ ramach etapu III postępowania pozwoliły także zidentyfikować kryteria doboru partnerów współpracy międzyorganizacyjnej. Dobór partnerów do współpracy wśród badanych przedsiębiorstw odbywał się w oparciu o jasno określone kryteria (wszystkie 53 przedsiębiorstwa potwierdziły ten fakt). Przedsiębiorstwa stosowały szereg kryteriów, z których najważniejszymi były: reputacja/prestiż podmiotu (średnia 5,75); stopień zaufania (średnia 5,70); dopasowanie 
zasobowe (średnia 5,55) partnerów; oraz dopasowanie strategiczne partnerów (średnia 5,51). Zaskakujący dla badaczy był fakt, iż w opinii ankietowanych, kryterium więzi personalnych (znajomości, przyjaźń) nie odgrywało istotnej roli (aż 41 na 53 badanych podmiotów nie potwierdziło stosowania powyższego kryterium przy doborze partnerów relacji). Można przypuszczać, iż tak niska ocena kryterium „więzi personalnych” może częściowo wynikać z wysokiej oceny kryterium „stopnia zaufania”. Respondenci prawdopodobnie doceniali jedynie te więzi personalne, które miały pozytywne konsekwencje w postaci wzrostu zaufania. Szczegółowe zestawienie wyników badań odnośnie kryteriów doboru partnerów prezentuje tabela 6 .

\section{Podsumowanie}

C elem artykułu było omówienie na gruncie teoretycznym i empirycznym jednej ze składowych treści strategii relacyjnej, jaką jest wybór kluczowych partnerów współdziałania. Zdaniem autorki, wybór kluczowych partnerów współdziałania międzyorganizacyjnego obejmuje dwa konstrukty myślowe: identyfikację typów partnerów relacji oraz identyfikację kryteriów selekcji tych partnerów, stąd oba zostały poddane analizie. W oparciu o krytyczną analizę literatury przedmiotu autorka zaproponowała własny podział typów podmiotów relacji oraz kryteriów ich selekcji, a następnie obie składowe poddała empirycznej egzemplifikacji na próbie 53 celowo dobranych, średnich pod względem wielkości przedsiębiorstw, działających na rynku polskim.

Uzyskane wyniki pozwoliły stwierdzić, że badane przedsiębiorstwa wchodziły w relacje międzyorganizacyjne $\mathrm{z}$ wieloma różnymi podmiotami, $\mathrm{z}$ których najczęściej były wskazywane cztery kategorie: klienci, dostawcy, organizacje finansowe oraz konkurenci. Największe znaczenie dla budowania przewagi konkurencyjnej analizowanych przedsiębiorstw miało wejście $\mathrm{w}$ relacje $\mathrm{z}$ : odbiorcami, dostawcami i organizacjami finansowymi.

Dobór partnerów do współpracy wśród badanych przedsiębiorstw odbywał się w oparciu o jasno określone kryteria. Przedsiębiorstwa stosowały szereg kryteriów, z których najważniejszymi były: reputacja/prestiż podmiotu, stopień zaufania, dopasowanie zasobowe partnerów oraz dopasowanie strategiczne partnerów. Z kolei za najmniej istotne kryterium selekcji partnerów ankietowani uznali kryterium więzi personalnych (znajomości, przyjaźń), co było dużym zaskoczeniem dla badaczy. Można przypuszczać, iż tak niska ocena kryterium „więzi personalnych” mogła wynikać z wysokiej oceny kryterium „stopnia zaufania”. Respondenci prawdopodobnie doceniali jedynie te więzi personalne, które miały pozytywne konsekwencje w postaci wzrostu zaufania.

Badane przedsiębiorstwa miały dużą swobodę w świadomym kształtowaniu relacji $\mathrm{z}$ różnymi podmiotami, bowiem nie były uwikłane $\mathrm{w}$ relacje, $\mathrm{z}$ których $\mathrm{z}$ różnych względów nie mogłyby się wycofać.

Co istotne, badane przedsiębiorstwa aktywnie i systematycznie rozwijały relacje jedynie $\mathrm{z}$ dwoma typami part- nerów: odbiorcami/klientami oraz dostawcami. Wyraźnie zabrakło rozwoju relacji z pozostałymi kategoriami podmiotów, $\mathrm{z}$ którymi badane podmioty miały już nawiązane relacje. Można zatem wnioskować, iż z perspektywy strategii relacyjnej, bardziej istotne jest aktywne i systematyczne rozwijanie relacji z kluczowymi partnerami, a nie sam fakt wejścia w te relacje.

$\mathrm{Z}$ racji niewielkiej próby badawczej (53 podmioty), zasadne jest zweryfikowanie uzyskanych wyników na dużej, losowo dobranej próbie przedsiębiorstw działają cych na polskim rynku. Warto zaznaczyć, iż takie badania są $\mathrm{w}$ trakcie realizacji.

\section{dr hab. Agnieszka Sopińska, prof. SGH Szkoła Główna Handlowa w Warszawie Katedra Zarządzania Strategicznego ORCID: 0000-0002-8421-3227 e-mail: asopin@sgh.waw.pl}

\section{Przypisy}

1) Projekt badawczy finansowany przez Narodowe Centrum Nauki nr UMO-2015/17/B/HS4/00982, pt. „Strategia relacyjna sensu largo przedsiębiorstw funkcjonujących w Polsce", realizowany pod kierunkiem prof. dr hab. Agnieszki Zakrzewskiej-Bielawskiej,

2) Oceny dokonywano na siedmiostopniowej skali Likerta, gdzie 1 - oznaczała, że dane relacje są nieistotne, zaś 7 - oznaczała relacje kluczowe dla uzyskania przewagi konkurencyjnej.

\section{Bibliografia}

[1] Aguezzoul A. (2014), Third-party Logistics Selection Problem: A Literature Review on Criteria and Methods, „Omega”, Vol. 49, pp. 69-78.

[2] Al-Khalifa A.K., Peterson S.E. (1999), The Partner Selection Process in International Joint Ventures, „European Journal of Marketing”, Vol. 33, No. 11/12, pp. 1064-1081.

[3] Angeles R., Nath R. (2003), Electronic Supply Chain Partnerships: Reconsidering Relationship Attributes in Customer-supplier Dyads, „Information Resources Management Journal", Vol. 16, No. 3, pp. 59-84.

[4] Angels R., Nath R. (2000), An Empirical Study of EDI Trading Partner Selection Criteria in Customer-supplier Relationships, „Information \& Management”, Vol. 37, pp. 241-255.

[5] Barringer B.R., Harrison J.S. (2000), Walking a Tightrope: Creating Value through Interorganizational Relationships, "Journal of Management", Vol. 26, No. 3, pp. 367-403.

[6] Billington C., Davidson R. (2013), Leveraging Open Innovation Using Intermediary Networks, „Production and Operation Management", Vol. 22, No. 6, pp. 1464-1465.

[7] Buttle F. (2004), Customer Relationship Management, Routledge.

[8] Cavusgil T.S., Evirgen C. (1997), Use of Expert Systems in International a Marketing, „European Journal of Marketing", Vol. 31, No. 1, pp. 73-86.

[9] Child J., Faulkner D., Tallman S.B. (2005), Cooperative Strategy, Oxford University Press. 
[10] Chin K.S., Chan B.L., Lam P.K. (2008), Identifying and Prioritizing Critical Success Factors for Coopetition Strategy, „Industrial Management \& Data Systems", Vol. 108, No. 4, pp. 437-454.

[11] Chun-ju Flora H. (2005), Exploring Types of Organization-public Relationships and their Implications for Relationship Management in Public Relations, „Journal of Public Relations Research", Vol. 17, No. 4, pp. 393-42.

[12] Czakon W. (2017), Świadomość sieciowa w strategiach relacyjnych, „Organizacja i Kierowanie”, Nr 2(176), s. 93-104.

[13] Dahl J., Kock S., Lundgren-Henriksson E.L. (2016), Conceptualizing Coopetition Strategy as Practice: A Multilevel Interpretative Framework, „International Studies of Management \& Organization”, Vol. 46, No. 2-3, pp. 94-109.

[14] De Witt B., Meyer R. (2007), Synteza strategii, PWE, Warszawa.

[15] Ding R., Dekker H.C., Groot T. (2013), Risk, Partner Selection and Contractual Control in Interfirm Relationships, „Management Accounting Research", Vol. 24, pp. 140-155.

[16] Duysters G., Kok G., Vaandrager M. (1999), Crafting Successful Strategic Technology Partnerships, „R\&D Management”, Vol. 29, No. 4, pp. 343-351.

[17] EFQM (2007), The EFQM Excellence Model, The European Foundation for Quality Management.

[18] Ellram L. (1990), The Supplier Selection Decision in Strategic Partnerships, „Journal of Purchasing and Materials Management", (Fall), pp. 8-14.

[19] Faulkner D., De Rond M. (eds.), (2000), Cooperative Strategy: Economic, Business and Organizational Issues, Oxford University Press.

[20] Feller J., Finnegan P., Hayes J., O’Reilly Ph. (2009), Institutionalizing Information Asymmetry: Governance Structures for Open Innovation, „Information Technology \& People”, Vol. 22, No. 4, pp. 297-316.

[21] Freeman R.E. (1984), Strategic Management: A Stakeholder Approach, Pitman Publishing Inc., Marshfield, MA.

[22] Freeman R.E., Reed D.L. (1983), Stockholders and Stakeholders: A New Perspective on Corporate Governance, „California Management Review", Vol. 25, No. 3.

[23] Hitt M.A., Dacin M.T., Levitas E., Arregle J.L, Borza A. (2000), Partner Selection in Emerging and Developed Market Contexts: Resource-Based and Organizational Learning Perspectives, „The Academy of Management Journal", Vol. 43, No. 3, pp. 449-467.

[24] Iyer K.S., Srivastava P., Rawwas M.A. (2014), Aligning Supply Chain Relational Strategy with the Market environment: Implications for Operational Performance, ,Journal of Marketing Theory \& Practice”, Vol. 22, No. 1, pp. 53-72.

[25] Klefsjö B., Bergqu B., Garvare R. (2008), Quality Management and Business Excellence, Customers and Stakeholders. Do We Agree on What We are Talking about, and Does it Matter? „The TQM Journal", Vol. 20, No. 2, pp. 120-129.

[26] Lasserre P. (1984), Selecting a Foreign Partner for Technology Transfer, „Long Range Planning”, Vol. 17, No. 6, pp. 43-49.

[27] Lau H., Lee W., Lau P.K.H. (2001), Development of an Intelligent Decision Support System for Benchmarking Assessment of Business Partners, „Benchmarking: An International Journal”, Vol. 8, No. 5, pp. 376-395.

[28] Lefaix-Durand A., Poulin D., Kozak R., Beauregard R. (2005), Interfirm Relationships and Value Creation: A Synthesis, Conceptual Model and Implications for Future Research, Working Paper DT-2005-DT-1, Université Laval, Qubeck, Canada.
[29] Malhotra N.K., Agarwal J. (2002), A Stakeholder Perspective on Relationship Marketing: Framework and Propositions, ,Journal of Relationship Marketing", Vol. 1(2), pp. 13-14.

[30] NIST (2008), Criteria for Performance Excellence, National Institute for Standard and Technology, Gaithersburg.

[31] Norma PN-EN ISO 26000:2009, Zarzadzanie odpowiedzialnością społeczną, Polski Komitet Normalizacyjny, Warszawa.

[32] Pidduck A.B. (2006), Issues in Supplier Partner Selection, "Journal of Enterprise Information Management", Vol. 19, No. 3, pp. 262-276.

[33] Sopińska A., Dziurski P. (2018) Otwarte innowacje. Perspektywa wspótpracy i zarzadzania wiedzą, Oficyna Wydawnicza SGH, Szkoła Główna Handlowa w Warszawie, Warszawa.

[34] Sopińska A., Mierzejewska W. (2017) Otwarte innowacje produktowe realizowane przez przedsiębiorstwa działajace $w$ Polsce. Podejście zasobowe, Oficyna Wydawnicza SGH, Szkoła Główna Handlowa w Warszawie, Warszawa.

[35] Stoner J.A.F., Freeman R.E., Gilbert D.R. Jr (1997), Kierowanie, Wyd. II, PWE, Warszawa.

[36] Yami S., Castaldo S., Dagnino B., Le Roy F. (red.), (2010), Coopetition: Winning Strategies for the 21st Century, Edward Elgar Publishing.

[37] Yan T., Azadegan A. (2017), Comparing Inter-organizational New Product Development Strategies: Buy or Ally; Supply-chain or Non-supply-chain Partners? „International Journal of Production Economies", Vol. 183, p. 23.

[38] Zakrzewska-Bielawska A. (red.), (2014), Koopetycja w rozwoju przedsiębiorstw high-tech. Determinanty i dynamika, Placet, Warszawa.

[39] Zakrzewska-Bielawska A. (2017), Wybory strategiczne w relacyjnej orientacji przedsiębiorstwa, „Handel Wewnętrzny”, $\mathrm{Nr}$ 3(368), s. 181-192.

\section{Partner Selection for Collaboration as a Component of Relational Strategy}

\section{Summary}

The paper aims to evaluate, theoretically and empirically, a partner selection for collaboration, which is perceived as a component of relational strategy. Partner selection for collaboration includes: identification of types of partners as well as criteria used to select them. The author evaluates both of them and presents her own classification of partners and criteria used to select them. The research result allows to formulate a thesis that establishing relations with partners does not mean active development of them. Most of enterprises consciously and systematically develop relationships with only two types of partners: clients/buyers and suppliers. Partner selection was based on clearly defined criteria. The most important ones included: reputation/prestige of the partner, degree of trust, resource and strategic alignment of partners. The least important criterion was personal ties.

\section{Keywords}

relational strategy, types of partners in collaboration, criteria used in partner selection 